\title{
The Sustainability Level of The Rice Farming in The Peatland at The Kapuas Regency, Central Kalimantan
}

\author{
Jhon Wardie ${ }^{1 *}$ and Tri Yuliana Eka Sintha ${ }^{1}$ \\ ${ }^{1}$ Agriculture Faculty, University of Palangka Raya \\ (Received March 20, 2018; accepted April 12, 2018; accepted April 16, 2018)
}

\begin{abstract}
The research aims to analyse the level of sustainability and the level of household income in the farming of rice on the peatland. The research location was determined by purposive sampling in Terusan Karya Village, Bataguh District, Kapuas Regency. The simple random sampling method was taken on 50 farmer household served as respondent. The data were collected in the form of primary and secondary data. To achieve the first research objective, it was conducted by an analysis of sustainability indicators of farming using Likert Scale system. The index of farming sustainability includes biophysical and socio-economic aspects in the rice farming on peatland. Meanwhile, to achieve the purpose of the second research, it was operated by using a simple tabulation to measure the level of farmer household income. The result of the analysis showed that farming sustainability of rice in the peatland found index by 76.10 percent, which means that the level of farming sustainability is a good category or highly sustainable. The result of the analysis of farm household income was 16.9 million rupiahs, which means that the farm household income has been categorized as good.
\end{abstract}

Keywords: sustainability index, peatland, income, rice, farmer household

JEL Classification: D10, Q01, Q12

\section{INTRODUCTION}

Agriculture still plays an essential role in fostering Indonesia's economy, so the government continues to give a particular attention to agricultural development. One of the main purposes of agricultural development in Indonesia is to improve food security so that the various efforts and innovations continue to do it. One attempt is to develop the role of how the agricultural sector which shows high productivity in the present and future. It is expected to meet the growing of food needs following the population growth, and to provide income for farmers.

A significant challenge in agricultural development is to develop of land resources that pay attention to the environment conservation and

\footnotetext{
* Corresponding author email: jwardie@agb.upr.ac.id, ISSN 2615-6075 online; ISSN 2615-6946 print @UWG Press, 2018

OJS http://publishing-widyagama.ac.id/ejournalv2/index.php/jsed/
}

natural resources. The agricultural development requires considering the implementation of the concept of sustainable development, which consists of three dimensions of development, covering economic, social and environmental aspects. The richness of natural resources has great potential to develop, including the agricultural land resources It should be managed optimally in supporting agricultural production regarding the quantity and quality, contributing economic output, providing economic prosperity for farmers, and maintaining biodiversity.

Significant agricultural land resources found on the island of Kalimantan are peatland. Peatlands have specific characteristics, whose management is no easier than mineral soil. The utilization of peatlands for agricultural production will face many obstacles, related to the low nutrients in the soil. That is why managing peatlands require particular attention and treatment (Ar-Riza, Nazemi, \& Rina, 2010). If there is a failure in management, then it can cause land degradation and environmental 
damage. Under these conditions, it will take a long time to rehabilitate and restore the land condition.

Thus, the agricultural development in peatlands should be carried out by following the concept of sustainable agriculture systems. The management of peatlands should adjust the characteristics of the land and pay attention to an eco-region. It can have implications for how the management of agricultural production by farmers' households, related to soil tilting, cultivation technology, labour, and farming cost needs. The optimal management of this land will produce maximum production and income for the farmers. This will create incentives for the farmers to develop peatland on the sustainable agricultural cultivation.

One model of sustainable agriculture management applied in peatland is a model of sustainable agriculture with the low external input use that is well-known as LEISA (Low External Input Sustainable Agriculture). This agricultural system attempts to reduce the use of inputs from the outside ecosystems such as seeds, chemical fertilizers, and pesticides. In the long term, using the system can strengthen the implementation of the sustainable management of agricultural systems (Reijntjes, Haverkort, \& Waters-Bayer, 1992).

Based on the background and descriptions above, the purpose of this study is to analyse the level of sustainability and the household income level of the farmers in rice farming on the peatland, in Terusan Karya Village, Bataguh District, Kapuas Regency.

\section{RESEARCH METHOD}

The area of research was determined purposively respecting the nature and character of the area. The area selected was considered to have close ties with the issues that will be examined, so it is relevant enough to the research objectives. Kapuas Regency is defined as the area of research that geographically covers an area of $8.554 \mathrm{~km} 2$ (57 percent) of the area's region particularly $14.999 \mathrm{~km} 2$ of ebb and peatland. Besides, the area is rice production centre for the province of Central Kalimantan.

In this study, there were 11 districts in the Southern Kapuas Regency which have characteristics as the region of ebb and peatland. The research area was determined purposively by choosing Terusan Karya Village, Bataguh district as the location for the research with the consideration that the location has the acreage of agricultural development in particular rice in the vast pea land. A simple random sampling was carried out to select 50 farmers as therespondents from the village. They performed a rational and intensive farming in managing and paying attention to the environmental sustainability based on the results of observation of the field, as well as from an interview with the field extension officers. The respondents selected are expected to represent the nature of the population of the farmers who manage the activity of farming in peatland.

The data collected in the research include primary data and secondary data. Primary data as the primary data were obtained through direct interviews with sample peasant using a structured list of questions as well as the direct observation on the object of the research. Meanwhile, the secondary data were collected from the variety of the office or related institutions with relevant supporting data.

The primary method used in this research was the descriptive method of analysis. The actual problem was accomplished systematically from the data acquired and collected for subsequent compiled, tabulated, analysed and described both qualitatively and quantitatively.

To conduct the first research objective, the level of sustainability of farming rice on-site research was analysed with the indicators of the sustainability assessment of the farmers by using Likert scale system. An indicator of the sustainability of farming is an instrument that contains the biophysics and socio-economic aspects. These are used to measure the level of sustainability of farming in the lowland ecosystems on the level of farming, and were adopted from the working paper on sustainable agriculture indicators (SEARCA, 1995).

To accomplish the second research objective, the assessment of the farming sustainability was calculated in the form of an index of sustainability, by adopting the equation of (Akdon \& Riduan, 2007) which was formulated as follows: 
sustainabilityindex $=\frac{\text { score obtained }}{\text { the maximumscore }} \times 100$

Sustainability index value will indicate the level of sustainability of farming categories as shown in Table 1 below.

Table 1. Category level of Sustainability of farming

\begin{tabular}{ccl}
\hline No & Index Value (\%) & \multicolumn{1}{c}{ Category } \\
\hline 1 & $0.00-25.00$ & Bad (not sustainable) \\
2 & $25.01-50.00$ & Less (less sustainable) \\
3 & $50.01-75.00$ & Enough (enough sustainable) \\
4 & $75.01-100.00$ & Good (very sustainable) \\
\multicolumn{2}{c}{ Source: Thamrin and team (Wardie, 2011). }
\end{tabular}

For achieving the second research purposes, the level of household income of the farmers was analysed in simple tabulations by using the following formula:

$$
\mathrm{I}=\mathrm{TR}-\mathrm{TVC}
$$

In which I = household income of farmers, TR Total revenue/total acceptance of farming, and TVC Total variable cost/total cost of farming issued

\section{RESULT AND DISCUSSION}

In managing farming, farmers should adequately carry out the application of a minimal input to obtain the maximum output, and will eventually receive an increased household income and the well-being of farmers.

Sustainable agriculture became the focus of attention because it is not only related to economic aspects and productivity economically but also needs to pay attention to the environmental and social issues. The term sustainable agriculture means developing agro-ecosystem that seeks to combine four things including productivity, stability, equity, and sustainability. The sustainability of paddy farming is measured by using sustainability assessment indicators. The results of the analysis in detail can be shown in Table 2 .

Table 2. Sustainability Index of rice farming on Peatland

\begin{tabular}{lccc}
\hline Activity & $\begin{array}{c}\text { The } \\
\text { Number of } \\
\text { Sample } \\
\text { (People) }\end{array}$ & $\begin{array}{c}\text { Sustainability } \\
\text { Index (\%) }\end{array}$ & $\begin{array}{c}\text { Category } \\
\text { Sustainability } \\
\text { Of Farming }\end{array}$ \\
\hline Farming rice & 50 & 76.10 & $\begin{array}{c}\text { Good (very } \\
\text { sustainable) }\end{array}$ \\
\hline
\end{tabular}

Table 2 shows that the achievement of sustainability indices of farming on rice farming activities in peat is 76.10 percent. It indicates that the sustainability level of farming in Terusan Karya Village, Bataguh district is sustainable or very good categories. This category is achieved because farmers in cultivating activities on their land performed an attitude and better behaviour in applying the biophysics and socio-economic aspects as the indicator of the sustainability. The management of peatland of the farmers associate with a model approach of LEISA. Farmers have identified the use of technology inputs and optimally worked land management. They have been able to suppress the use of external inputs, and instead use external inputs and optimally apply input from the local resources.

Peatland resource development cannot be generalized to all regions. Peatlands are extremely fragile and sensitive to environmental changes, so these need appropriate methods and management practices. The application of technology should be based on the consideration of land characteristics, suitability, efficiency and synergy between specific technology and environment components so that the sustainability of production can be more ensured. Peatland management also considers the conditions of biodiversity to support ecosystem balance. Peatland cultivation technology employs an application of dolomite, compost, macro and macro fertilizer; high yield variety, inter-cropping; and land preparation without burning (Ar-Riza et al., 2010).

According to (SEARCA, 1995), there are two aspects of assessing levels of farming sustainability, namely biophysics and socio-economic aspects. An indicator of sustainable farming denoted biophysics aspects includes the land quality, the use of external and the internal inputs as well as effluent recycling. Meanwhile, the aspect of socio-economic covers diversified sources of revenue (from onfarm, off-farm, and non-farm), harvesting systems, practice management of farming, ownership, and control of land, food security, membership in the organization and support services.

To meet the needs of daily life, farmers have to do household activities. In general, the business of the farmer household can be divided into three things, namely the on-farm activities, the off-farm 
and the non-farm. However, this study only analysed household income sourced from the onfarm activities. On-farm income of the household originated from the rice farming, crops, vegetables, fruits plant, and livestock business venture, as it can be seen in Table 3.

Table 3. Sources of On-Farm Household Income of farmers

\begin{tabular}{|c|c|c|c|}
\hline \multirow{2}{*}{ No } & \multirow{2}{*}{ Type of Farming } & \multicolumn{2}{|c|}{ Household Income } \\
\hline & & Value & Proportion \\
\hline & & Rp 1000/year & $\%$ \\
\hline 1 & Rice & 8164.3 & 48.3 \\
\hline 2 & $\begin{array}{l}\text { Food crops and } \\
\text { vegetables }\end{array}$ & 508.6 & 3.0 \\
\hline 3 & Fruit plant & 6079.8 & 36.0 \\
\hline 4 & Livestock & 2153.9 & 12.7 \\
\hline & Total & 16906.6 & 100.0 \\
\hline
\end{tabular}

Table 3 shows that an on-farm income source comes mainly from the farming rice that contributes 48.29 percent of the total income. Meanwhile, the smallest income source found in the crops and vegetables farming contribute 3.01 percent total income. It is very reasonable because the rice farming is the primary commodity for the farmers' household in contributing revenue. Meanwhile, for the cultivation of crops and vegetables grown is only on the land area with a relatively small size.

The Household Income Survey of Farmer (SPP) by 2013 noted that the average farm household income from farming businesses in the province of Central Kalimantan was 16.491 million rupiahs (BPS, 2014). This figure shows a significant increase compared with the similar survey done in 2004 as the amount of 8.240 million rupiahs (BPS, 2004). In this research, farm household income reached 16.906 million rupiahs. This figure exceeds slightly from the results of the SPP survey in 2013.

Meanwhile, research results from (Heryono, Nugroho, \& Hanafie, 2016) found different results in Lumajang, East Java. The research on the intensive paddy field (with productivity average of 8.0 tons per hectare), the income of rice farmers amounted to 37.737 and 31.280 million rupiahs each for farmers who are members of a group and a non farmer group. This result is much higher than rice productivity in peatlands. The productivity level of a high yield variety of rice in peatlands was about 4.0 tons per hectare (Syafruwardi, Fajeri, \&
Hamdani, 2012). However, in general, from the evaluation of the sustainability of income level, household earns income on the average above 10 million rupiahs per year which is categorized as good.

\section{CONCLUSION AND SUGGESTION}

The level of sustainability of the rice farming in peatland of Terusan Karya Village, Batagus District, Kapuas Regency is well categorized or very sustainable. It means that the household farmers already have positive attitudes and behaviour that is against the principles and nature of sustainable farming.

The household income level of farmers in the Terusan Karya Village, Batagus District, Kapuas Distric is high. This means that household economic circumstances of farmers are already well categorized.

Farm households should continue to improve their positive attitudes and behaviours in applying the principles of sustainable agriculture and natural resources management. These efforts will increase agricultural production and economic value, build a healthy and secure society for sustainable natural resource development.

In addition to the rice, farmers can develop other farming such as food crop, vegetables, fruits, and livestock business either as a primary livelihood or side business. It requires support from the local government agricultural agency.

\section{REFERENCES}

Akdon, \& Riduan. (2007). Rumus dan Data dalam Analisis Statistika untuk Penelitian. Bandung: Alfabeta. Retrieved from https://opac.perpusnas.go.id/DetailOpac.aspx?i $\mathrm{d}=411962$

Ar-Riza, I., Nazemi, D., \& Rina, D. Y. (2010). Penerapan teknologi tanpa bakar untuk meningkatkan produksi jagung di lahan gambut. In Prosiding Pekan Serealia Nasional, Maros, 27-28 Juli 2010 (pp. 287-293). Maros: Balitbang Pertanian, Kementan. Retrieved from http://balitsereal.litbang.pertanian.go.id/wpcontent/uploads/2016/12/p37.pdf

BPS. (2004). Agricultural Census 2003. Household Income Survey Results of Agricultural Business (SPP). Palangka Raya: Central Bureau of Statistics of The Province of Central Kalimantan. 
BPS. (2014). Agricultural Census 2013. Household Income Survey Results of Agricultural Business (SPP) Province of Central Kalimantan (2014). Palangka Raya: Central Bureau of Statistics of The Province of Central Kalimantan.

Heryono, M., Nugroho, I., \& Hanafie, R. (2016). Analysis of Efficiency on Rice Farming. Agricultural Socio-Economics Journal, 16(1), 31-37. https://doi.org/10.6084/m9.figshare.6265214

Reijntjes, C., Haverkort, B., \& Waters-Bayer, A. (1992). Farming for the future: an introduction to low-external-input and sustainable agriculture. Farming for the Future: An Introduction to Low-External-Input and Sustainable Agriculture. Retrieved from https://books.google.co.id/books/about/Farmin $\mathrm{g}$ for the Future.html?id=Ek4fAQAAIAAJ\&redir esc $=y$

SEARCA. (1995). Working paper on sustainable agriculture indicators. Sustainable agriculture indicators. Laguna, Philippines: SEAMEO Regional Center for Graduate Study and Research in Agriculture (SEARCA). Retrieved from

https://catalog.hathitrust.org/Record/00939190 $\underline{6}$

Syafruwardi, A., Fajeri, H., \& Hamdani. (2012). Analisis Finansial Usahatani Padi Varietas Unggul di Desa Guntung Ujung Kecamatan Gambut Kabupaten Banjar Kalimantan Selatan. Agribisnis Pedesaan, 2(3), 181-192. Retrieved from

https://media.neliti.com/media/publications/924 7-ID-analisis-finansial-usahatani-padi-varietasunggul-di-desa-guntung-ujung-kecamata.pdf

Wardie, J. (2011). Sustainable Farming Optimization at Local Farm Household and Non Local Household in Tidal Swamps Area in Kapuas Regency. PhD Thesis. University of Gadjah Mada, Yogyakarta. Retrieved from http://ugm.summon.serialssolutions.com/2.0.0/1 ink?t=1580429817046 